\title{
Antitumor effect and immune response induced by local hyperthermia in B16 murine melanoma: Effect of thermal dose
}

\author{
DAN YE LI ${ }^{1,2}$, YANG PING TANG ${ }^{2,3}$, LING YUN ZHAO ${ }^{2}$, CHUAN YING GENG $^{4}$ and JIN TIAN TANG ${ }^{1,2}$ \\ ${ }^{1}$ Department of Oncology, Xiangya Hospital, Central South University, Changsha, Hunan 410008; \\ ${ }^{2}$ Key Laboratory of Particle and Radiation Imaging, Ministry of Education, Department of Engineering Physics, \\ Tsinghua University, Beijing 100084; ${ }^{3}$ Department of Bio-Pharmaceutics, Beijing University of Chinese \\ Medicine, Beijing 100102; ${ }^{4}$ China-Japan Friendship Hospital, Beijing 100029, P.R. China
}

Received March 14, 2012; Accepted June 12, 2012

DOI: 10.3892/ol.2012.804

\begin{abstract}
This study aimed at investigating the antitumor effect and immune response induced by local high-temperature hyperthermia at different thermal doses in $\mathrm{B} 16$ murine melanoma. The screened optimal thermal dose $\left(50^{\circ} \mathrm{C}, 15 \mathrm{~min}\right)$ which was demonstrated to be the most effective in immune response activation was applied to the treatment of lung metastasis. The optimal thermal dose was determined by evaluating the tumor volume change, survival period of tumorbearing mice, and immune indices including interleukin (IL)-2, interferon (IFN)- $\gamma$ and TNF- $\alpha$ mRNA expression in the spleen of mice subjected to local hyperthermia at various thermal doses. The activation of the immune response was further investigated by rechallenging the cured mice 60 days after hyperthermia treatment. The screened optimal thermal dose combined with immunoadjuvant compound 48/80 was applied for melanoma lung metastasis. While local hyperthermia effectively inhibited B16 melanoma tumor growth and prolonged the survival period of tumor-bearing mice, the antitumor immunity was significantly enhanced and the effect was thermal dose-dependent. Higher temperatures $\left(\geq 50^{\circ} \mathrm{C}\right)$ induced a significant effect even with a short treatment time ( $\leq 15 \mathrm{~min}$ ). No tumor regrowth was observed for rechallenged B16 melanoma in mice following treatment with local hyperthermia at a higher temperature. Local hyperthermia by optimal thermal dose in combination with immunoadjuvant compound 48/80 is an effective approach for the treatment of B16 melanoma lung metastasis. This study indicated that the
\end{abstract}

Correspondence to: Associate Professor Ling Yun Zhao or Professor Jin Tian Tang, Key Laboratory of Particle and Radiation Imaging, Ministry of Education, Department of Engineering Physics, Tsinghua University, Tsinghuayuan Street, Haidian, Beijing 100084, P.R. China

E-mail: lyzhao@tsinghua.edu.cn

E-mail: tangjt@tsinghua.edu.cn

Key words: local hyperthermia, B16 melanoma, lung metastasis, thermal dose, immunity-response use of a local high-temperature hyperthermia protocol inhibits tumor growth and stimulates a favorable antitumor immune response against malignant melanoma. The results of these experiments may have clinical significance for the treatment of melanoma.

\section{Introduction}

Melanoma is a malignant tumor originating from melancytes that constitute the human body's melancytic system. As one of the most lethal types of cancer in humans, malignant melanoma accounts for $75 \%$ of all mortalities associated with skin cancer. Although malignant melanoma in the early stage may be cured by surgical resection, the disease is notoriously difficult to treat and does not respond to current therapies once it has progressed to the metastatic stage. For instance, therapies including immune therapy with systemic high-dose interleukin (IL)-2 or interferon (INF)- $\alpha$, antigen-specific immunization or chemotherapy with dacarbazine or temozolomide have been shown to induce objective tumor responses in only 5-20\% of patients. It has also been reported that patients with pulmonary metastases have an overall 5-year survival rate of $4 \%$ and a median survival of only 6-7 months with palliative treatment. Therefore, a more effective protocol for the prevention and therapy of malignant melanoma is urgently needed (1-4).

As an effective, safe, minimally invasive or noninvasive approach, hyperthermia is capable of directly killing tumor cells and acts as a sensitizer for radiation therapy or chemotherapy, as demonstrated in numerous clinical studies $(5,6)$. As a superficial tumor, melanoma can easily be administered local hyperthermia from the clinical point of view. Either as a monotherapy or as an adjuvant therapy with other treatments, such as chemotherapy or radiotherapy, the results of hyperthermia treatment from clinical trials and in vivo studies are encouraging, suggesting a promising protocol for malignant melanoma (7-9).

As a dominant parameter of hyperthermia, temperature acts as a sensitive regulator during the treatment. Results from previous studies have shown that malignant melanoma may be even more sensitive to temperature $(8,9)$. Studies of hyperthermia have been focused on two commonly applied strategies: conventional hyperthermia at mild temperatures 
$\left(42-45^{\circ} \mathrm{C}\right)(6,8,9)$ and ablation therapy at high temperatures $\left(>70^{\circ} \mathrm{C}\right)(10)$. Stojkovic and Radacic reported that local hyperthermia of $43.5^{\circ} \mathrm{C}$ administered alone had good antitumor activity, as in all experiments tumor growth time was prolonged by 2.3-3.5 times compared with the control (8). Results from the study of Ito et al suggested that a temperature of $43^{\circ} \mathrm{C}$ was insufficiently high to destroy the malignant melanoma and a higher treatment temperature was proposed (9). However, the induced antitumor immunity of thermal ablation was found to be weak and possibly not sufficient to eradicate established tumors alone (10). A study by Zhou et al suggested that the thermal ablation of hepatoma at $50 \pm 5^{\circ} \mathrm{C}$ may promote maturing and homing of immature dendritic cells (DCs) and stimulate immunity of lymphocytes, but not at temperatures $>60^{\circ} \mathrm{C}$. The immunogenicity of tumor cells was lost when their cellular structures were completely destroyed, and the local tissue blood flow and local lymph circulation path were damaged as the heat temperature was too high, which prevented the homing of the DCs (11). All the above-mentioned studies highlight the fact that the choice of treatment protocol is critical in the evaluation of the therapeutic effect of hyperthermia, and as a result, temperatures between 46 and $55^{\circ} \mathrm{C}$ were used in this study.

In our study, the effect of local hyperthermia on the antitumor effect and immune response in B16 melanoma at various thermal doses was systematically analyzed. Local hyperthermia can result in higher temperatures compared with whole body hyperthermia, which heats to milder temperatures of around $41-43^{\circ} \mathrm{C}$. In order to eliminate the effect of energy from hyperthermia, a specially designed biological hyperthermia platform using hot humidified vapor was adopted in the current study. The tumor area was heated at various temperatures by the hot vapor from the nozzle. A series of nozzles with different diameters were prepared to fit the actual tumor size of the mice. Evaluation of the tumor volume and survival period as well as histological analysis was employed to examine the antitumor effect of local hyperthermia at different thermal doses. In addition, tumor necrosis factor (TNF)- $\alpha$, IL-2 and IFN- $\gamma$ mRNA expression in the spleen of mice were evaluated by relative quantitative RT-PCR for a detailed understanding of the immune response induced by hyperthermia. The preliminary detection of cytokines IL-2, IFN- $\gamma$ and TNF- $\alpha$ in hyperthermia was performed using ELISA and focused mainly on the cytokine protein in serum and tumor tissues. In this study, the changes in IFN- $\gamma$, IL- 2 and TNF- $\alpha$ mRNA levels in the spleen were investigated from a genetic perspective by relative quantitative PCR assay. The rechallenge of the surviving mice with B16 tumor cells confirmed that the mice had developed long-term tumor-specific immunity against malignant melanoma following hyperthermia at the optimal thermal dose. Compound 48/80 (C48/80) is a stimulus of mast cell degranulation $(12,13)$. It has been reported that the mast cell activator C48/80 was an effective and safe adjuvant for the induction of anthrax lethal toxin neutralizing antibody responses when delivered intranasally, intradermally or via the footpad to mice with anthrax protective antigen $(13,14)$. However, few studies were found concerning the use of $\mathrm{C} 48 / 80$ in tumor treatment; therefore, in the present study, local hyperthermia combined with $\mathrm{C} 48 / 80$ was applied for melanoma lung metastasis treatment. This study aimed to establish a local hyperthermia protocol for B16 melanoma. The results of the experiments may have clinical significance for melanoma treatment.

\section{Materials and methods}

Cell line and cell culture. The murine B16-F10 melanoma cell line was obtained from Cell Center, Institute of Basic Medical Sciences, Chinese Academy of Medical Sciences and Peking Union Medical College, China. The cells were cultured in Dulbecco's modified Eagle's medium (DMEM) supplemented with $10 \%$ heat-inactivated fetal bovine serum, $100 \mathrm{U} / \mathrm{ml}$ penicillin and $100 \mu \mathrm{g} / \mathrm{ml}$ streptomycin. The cell cultures were maintained at $37^{\circ} \mathrm{C}$ in a $5 \% \mathrm{CO}_{2}$ humidified atmosphere at $\mathrm{pH}$ 7.4. When the cells reached $90 \%$ confluence, a cell suspension was obtained by trypsinization.

Animal and tumor models. Male C57BL/6 mice (aged 8 weeks) were purchased from the Hsing-Long laboratory animal breeding center (Beijing, China). Throughout the experiment, the animals were housed four or five per cage in standard cages. The animals were kept in these facilities for at least 3 days prior to the experiments. All protocols were approved by the Institutional Animal Care and Use Committee (IACUC) of Tsinghua University, Beijing, China.

To create a murine model for melanoma skin cancer, B16 tumor cells ( $1 \times 10^{6}$ in $100 \mu$ PBS) were injected into the flank of mice which were anesthetized by intraperitoneal injection of sodium pentobarbital ( $50 \mathrm{mg} / \mathrm{kg}$ body weight). Melanoma nodules that had grown to $5-6 \mathrm{~mm}$ in diameter were used for the experiment.

The murine model for melanmoma pulmonary metastasis was developed by administration of B16 cell suspension $\left(1 \times 10^{6}\right.$ cells) through the tail vein of the mice. Histological evalution was performed 14 days after the administration of cell suspension.

Animal groups and local hyperthermia for melanoma skin tumor model. A total of 150 mice with melanoma nodules were randomly divided into five groups: group I formed the control group, group II received $46^{\circ} \mathrm{C}$ hyperthermia for $15 \mathrm{~min}$, group III received $48^{\circ} \mathrm{C}$ hyperthermia for $15 \mathrm{~min}$, group IV received $50^{\circ} \mathrm{C}$ hyperthermia for $15 \mathrm{~min}$ and group $\mathrm{V}$ received $55^{\circ} \mathrm{C}$ hyperthermia for $10 \mathrm{~min}$. As we observed in our preliminary experiment, certain mice died of dehydration under $55^{\circ} \mathrm{C}$ hyperthermia for $15 \mathrm{~min}$, therefore a 10 -min treatment was adopted for group V. Mice were anesthetized with $1 \%$ pentobarbital and subjected to hyperthermia using the heating and humidification biological platform (Fig. 1). The temperature was measured at the tumor center and in the rectum by a 0.1-mm thermocouple temperature probe (Model IT-18, copper-constantan, Physitemp, New Jersey, USA) inserted into the tumor tissue and rectum, respectively. The probe fibers were connected to a four-channel millivoltmeter (model XSOL-4, Beijing Kunlun Tianchen Instrument Technology, Co., Ltd, Beijing, China) and the data were collected every $6 \mathrm{sec}$ using a PC with home-written software.

After inducing hyperthermia, the long and short axes of the tumors were measured with digital calipers at 1-2-day intervals, and tumor volumes were calculated using the formula: $V=1 / 2 \times A^{2} \times B$, where $A$ is the length of the short axis and 
Table I. Reaction mixture used for reverse transcription of cDNA.

\begin{tabular}{lc}
\hline & Amount \\
\hline Positive control RNA & $2 \mu \mathrm{g}$ \\
Oligo $(\mathrm{dT})_{15}$ & $2 \mu \mathrm{l}$ \\
dNTP mixture $(10 \mathrm{mM})$ & $5 \mu \mathrm{l}$ \\
RNase inhibitor & $1 \mu \mathrm{l}$ \\
M-MLV reverse transcriptase $(200 \mathrm{U} / \mu \mathrm{l})$ & $1 \mu \mathrm{l}$ \\
$5 \mathrm{X}$ M-MLV RT buffer & $5 \mu \mathrm{l}$ \\
RNase free $\mathrm{dH}_{2} \mathrm{O}$ & Added to make $25 \mu \mathrm{l}$
\end{tabular}

Table II. Reaction mixture used for PCR.

\begin{tabular}{lr}
\hline & Amount \\
\hline cDNA templates & $2 \mu 1$ \\
2X SYBR-Green PCR Master mix & $12.5 \mu 1$ \\
Upstream primers $(0.9 \mathrm{nmol} / \mu \mathrm{l})$ & $1 \mu \mathrm{l}$ \\
Downstream primers $(0.9 \mathrm{nmol} / \mu \mathrm{l})$ & $1 \mu \mathrm{l}$ \\
Double-distilled water & $8.5 \mu \mathrm{l}$ \\
Total & $25 \mu \mathrm{l}$ \\
\hline
\end{tabular}

$B$ is the length of the long axis. Surviving mice were counted until all group II mice had died. Survival rates were recorded as percentage survivals.

Histopathological analysis. At $16 \mathrm{~h}$ and at 7 days after the hyperthermia treatment was completed, a necropsy was performed after the animals were sacrificed and organs were placed immediately into $10 \%$ neutral-buffered formalin (NBF). Tissues were processed and embedded in paraffin and sectioned at $6 \mu \mathrm{m}$. Sections were stained with hematoxylin and eosin (H\&E) from routine histological evaluation. Six randomly selected animals per group were used in the experiments. Tumor tissues were analyzed in 5 randomly selected fields per section.

Detection of cytokine mRNA in the spleen using RT-PCR. Spleens were collected from randomly selected mice in each group at 7 and 14 days after the hyperthermia treatment was completed. RNA was prepared by homogenization of the tumor with RNAzol followed by RNA extraction according to the manufacturer's instructions. RNA concentrations were measured, and $2 \mu \mathrm{g}$ total cellular RNA was reverse transcribed in a $200-\mu$ l volume using oligo(dT) ${ }_{15}$ as a primer and Moloney murine leukemia virus reverse transcriptase. cDNA $(2 \mu 1)$ was amplified by PCR using primers specific to individual murine cytokines. The reaction mixtures used in the reverse transcription of cDNA and PCR are shown in Tables I and II.

Rechallenge. Mice with complete tumor regression which were cured by local hyperthermia were rechallenged with B16 melanoma cells (approximately $1 \times 10^{6}$ cells) by subcutaneous

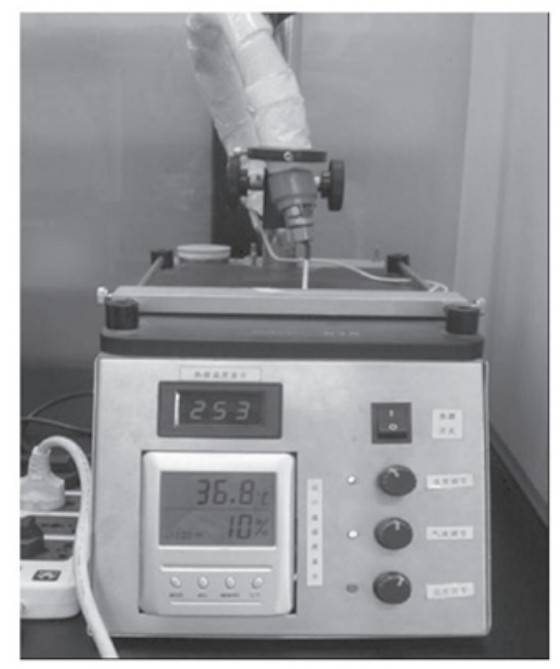

Figure 1. Heating and humidification instrument.

inoculation on the right side abdomen 60 days after hyperthermia treatment. The tumor growth and survival time of the mice were observed.

Combined therapy for lung metastasis treatment. Mice were randomly divided into three groups. Group I formed the control group, which received no treatment. In group II (PBS + hyperthermia group), local subcutaneous tumors were heated to $50^{\circ} \mathrm{C}$ and maintained for $15 \mathrm{~min}$, then PBS was injected into the tumors locally following hyperthermia treatment. In group III (C48/80 + hyperthermia group), local subcutaneous tumors were heated to $50^{\circ} \mathrm{C}$ and maintained for $15 \mathrm{~min}$, then $\mathrm{C} 48 / 80$ was injected into the tumors locally following hyperthermia. The heating method was the same as that used in the thermal dose filtering experiment.

Statistical analysis. All experiments were repeated at least twice. SPSS 10.0 statistical software was applied for analysis. Variances were homogeneous in each group and a q-test was used to analyze the variance between the means in groups. Differences between the means were considered statistically significant at $\mathrm{P}<0.05$, and were considered highly significant at $\mathrm{P}<0.01$. MxPro QPCR 3.20 software was used for analysis of RT-PCR data to obtain $\mathrm{Ct}$ values.

\section{Results}

Temperature monitoring in local hyperthermia. Target temperatures at the center of the tumors were attained within 2-4 min and maintained by controling the thermal current intensity. The temperature in the rectum increased only slightly, and was maintained within the normothermic range (approximately $37^{\circ} \mathrm{C}$ ) during heat treatment. All experimental animals tolerated the hypothermic treatment well (Fig. 2).

Tumor growth following hyperthermia. Tumor volumes in the 46 and $48^{\circ} \mathrm{C}$ groups were significantly reduced compared with those in the control group $(\mathrm{P}<0.05)$. Inhibition of tumor growth by hyperthermia at 50 and $55^{\circ} \mathrm{C}$ was particularly effective $\left(\mathrm{P}<0.01\right.$; Fig. 3). One of the mice in the $50^{\circ} \mathrm{C}$ group exhibited 


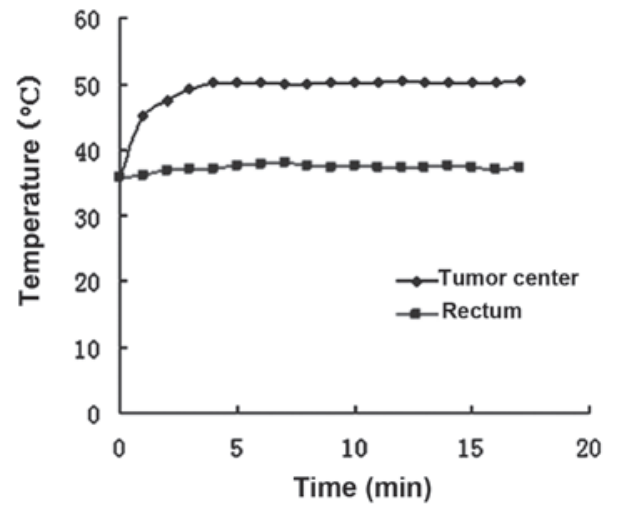

Figure 2. Temperature change curve of a randomly selected tumor-bearing mouse in $50^{\circ} \mathrm{C}$ group.

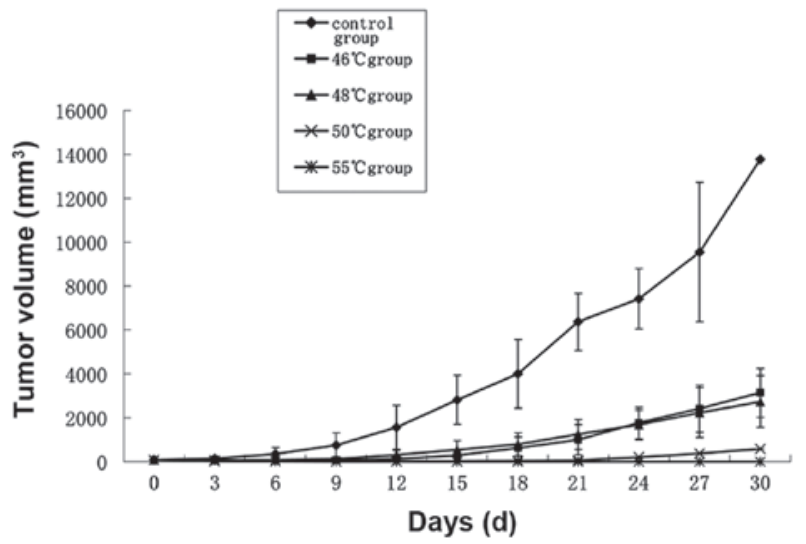

Figure 3. Tumor growth following hyperthermia treatment. All data are expressed as mean \pm standard deviation $(\mathrm{SD})(\mathrm{n}=6)$.

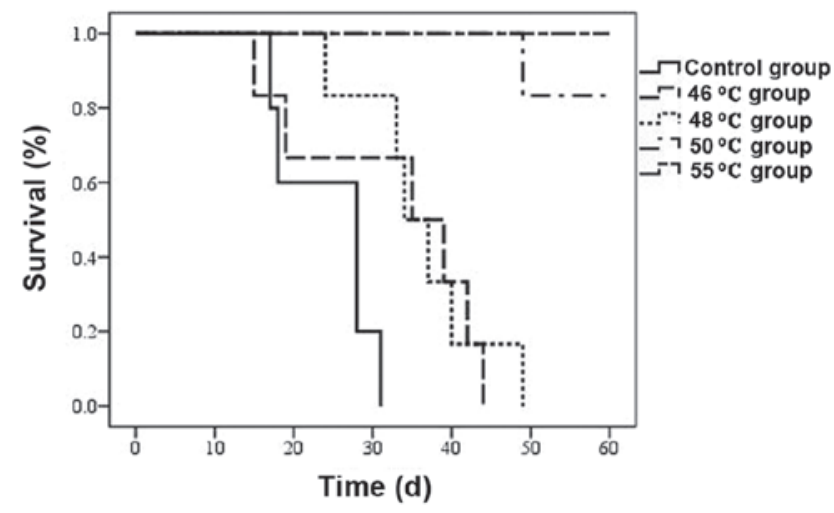

Figure 4. Survival curve over a period of 60 days following hyperthermia treatment. $\mathrm{n}=6$ mice/group, $\mathrm{T}=0$ corresponds to the time of hyperthermia.

tumor growth 15 days after treatment, the remainder of the group and all mice in the $55^{\circ} \mathrm{C}$ group remained tumor-free. Two mice in the $55^{\circ} \mathrm{C}$ group suffered burns to the skin in the process of heating.

Survival of tumor-bearing mice. As shown in Fig. 4, the survival of tumor-bearing mice was prolonged by hyper-
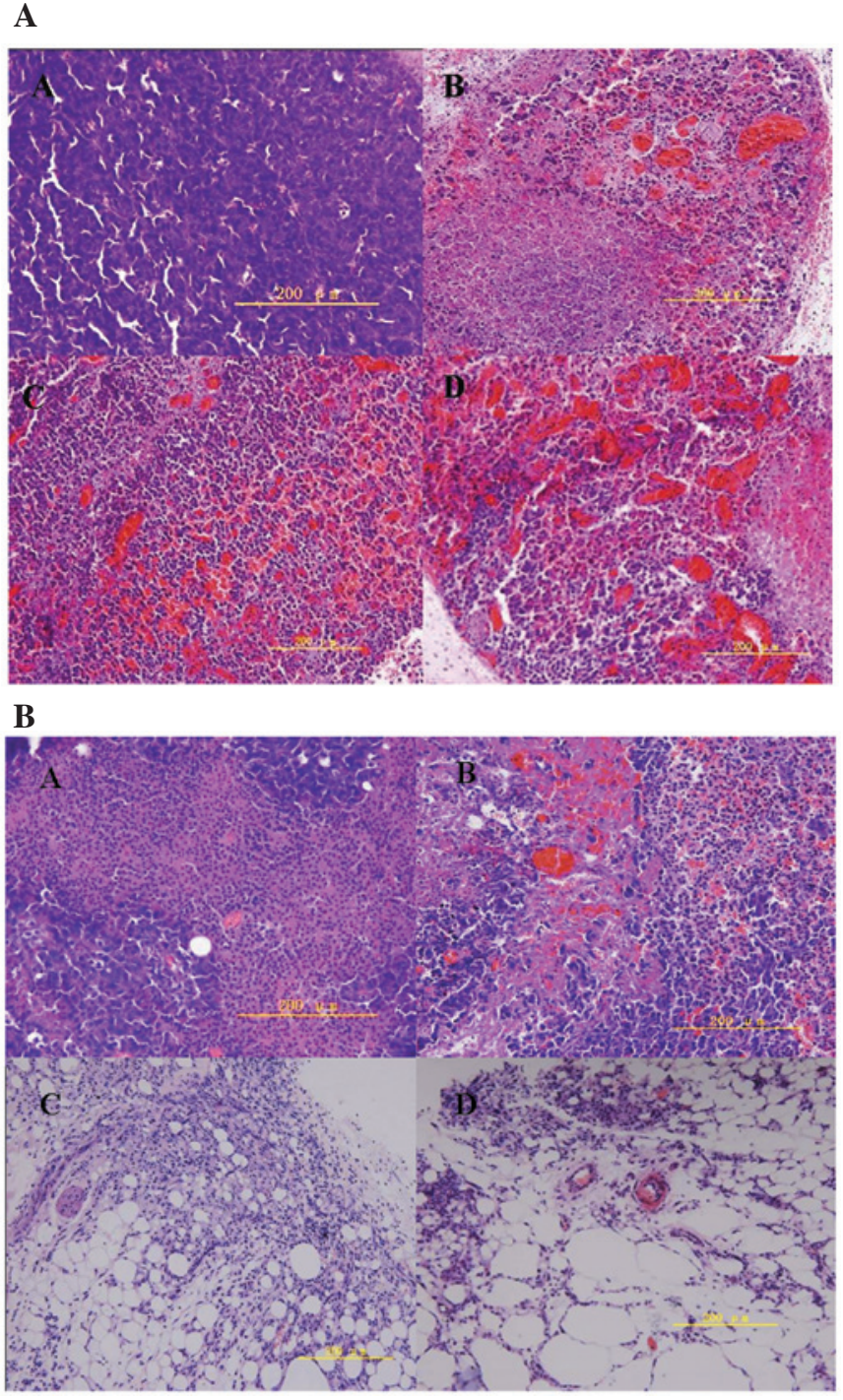

Figure 5. Histopathology of tumors with H\&E staining (A) $16 \mathrm{~h}$ and (B) 7 days after hyperthermia treatment. Magnification, x400; bar, $200 \mu \mathrm{m}$. Top left, control group; top right, $46^{\circ} \mathrm{C}$ group; bottom left, $50^{\circ} \mathrm{C}$ group; bottom right, $55^{\circ} \mathrm{C}$ group. (A) Fewer tumor cells were observed in the treated groups than in the control. Hemorrhage increased as the treatment temperature increased. (B) Fat vacuoles were observed in the 50 and $55^{\circ} \mathrm{C}$ group, with no tumor cells.

thermic treatment in all four treatment groups $(\mathrm{P}<0.05)$, and this was most evident in the 48,50 and $55^{\circ} \mathrm{C}$ groups $(\mathrm{P}<0.01)$. One of the mice in the $50^{\circ} \mathrm{C}$ group died on the 48th day due to tumor growth. The remaining five mice in the $50^{\circ} \mathrm{C}$ group and all mice in the $55^{\circ} \mathrm{C}$ group survived for a period of 60 days following hyperthermia treatment.

Histopathological observation of tumors. As shown in Fig. 5A, large numbers of actively proliferating tumor cells were observed in the center of the tumors in the untreated control group (top left) $16 \mathrm{~h}$ after the start of the experiments. There was obvious chromatorrhexis and dissolution of tumor cells in the hyperthermia groups, as well as blood vessel destruction within tumors. Tumors showed increased signs of necrosis, congestion and hemorrhage as the temperature increased. Seven days after hyperthermia treatment, there was an obvious decrease in the quantity of tumor cells and increased tumor tissue hemorrhage in the treated groups as the temperature 
$\mathbf{A}$

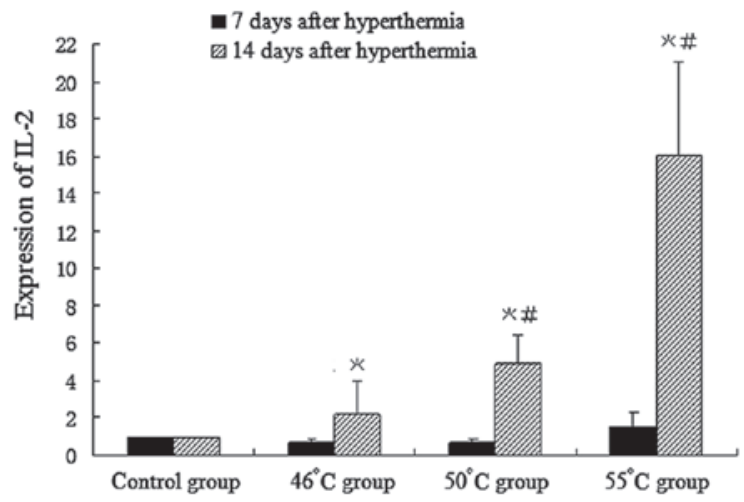

B

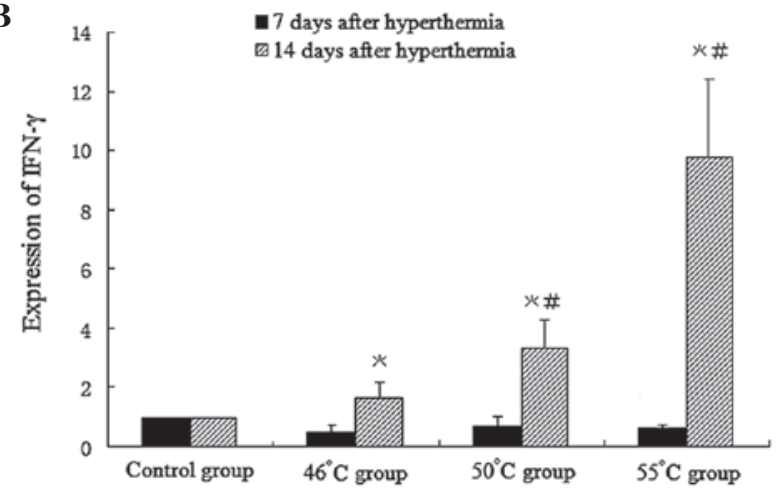

C

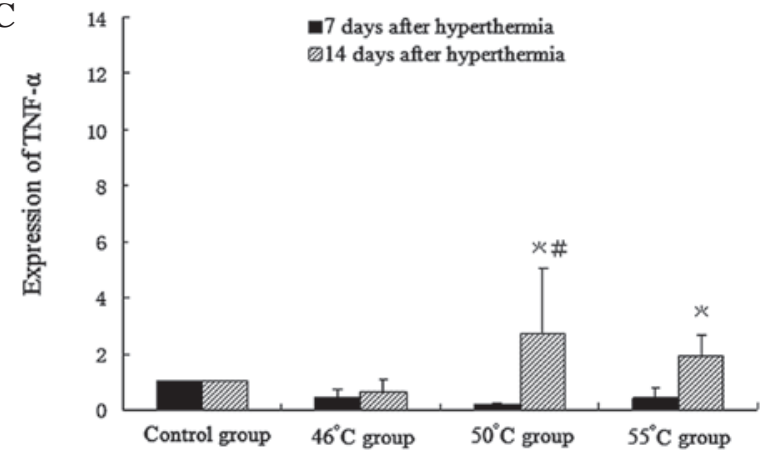

Figure 6. Cytokine mRNA expression 7 and 14 days after hyperthermia treatment was measured by RT-PCR. (A) IL-2, (B) IFN- $\gamma$, and (C) TNF- $\alpha$ mRNA. Taking mRNA in the control as 1 , folds of mRNA in treatment groups relative to the control are shown. All data are expressed as mean $\pm \mathrm{SD}\left(\mathrm{n}=6,{ }^{*} \mathrm{P}<0.05\right.$ compared with the control group; ${ }^{*} \mathrm{P}<0.05$ compared with the $46^{\circ} \mathrm{C}$ group). IL, interleukin; IFN, interferon; TNF, tumor necrosis factor.

increased, compared with those in the control group (Fig. 5B). Tumors in the 50 and $55^{\circ} \mathrm{C}$ groups disappeared completely 14 days after hyperthermia treatment, and white knots were formed hypodermically, which on macroscopic pathological observation were found to contain many fat vacuoles.

Expression of IL-2, IFN- $\gamma$ and TNF- $\alpha$ mRNA in mouse spleens. Compared with the control group, except for a slight increase in IL-2 mRNA expression in the $55^{\circ} \mathrm{C}$ group, there was a slight decrease in the expression levels of IL-2, IFN- $\gamma$ and TNF- $\alpha$ mRNA in all groups 7 days after hyperthermic treatment. After 14 days, compared with the control group, IL-2 and IFN- $\gamma$ mRNA expression increased significantly in all hyperthermia groups (1.64-fold in the $46^{\circ} \mathrm{C}$ group, 3.32 -fold

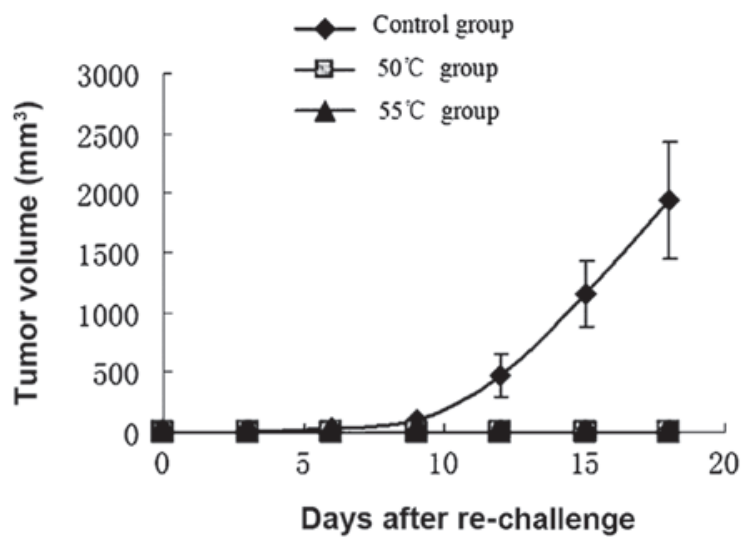

Figure 7. Tumor growth of B16 tumor-bearing mice following tumor rechallenge during treatment. Mean $\pm \mathrm{SD}$ of $\mathrm{n}=6$ mice/group in all groups.

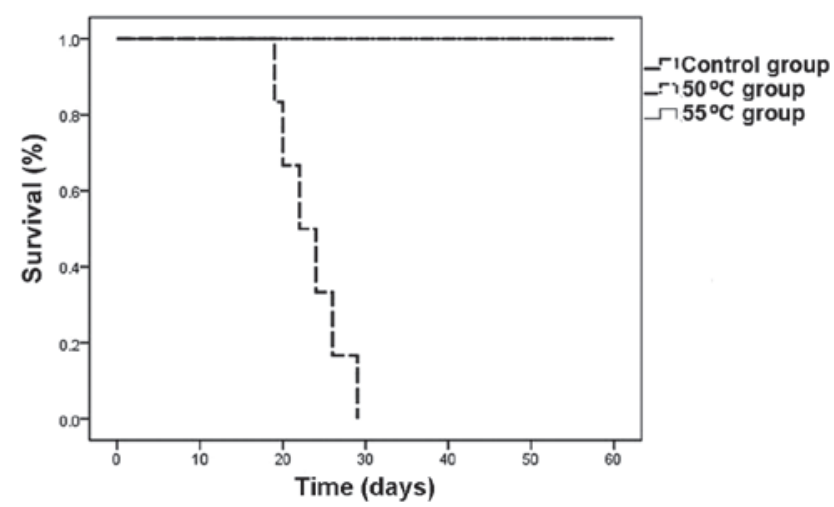

Figure 8. Survival curve over a period of 60 days in mice rechallenged with tumor cells after treatment with hyperthermia. $n=6$ mice/group in control group and $55^{\circ} \mathrm{C}$ group, $\mathrm{n}=5$ in $50^{\circ} \mathrm{C}$ group. $\mathrm{T}=0$ corresponds to the time of hyperthermia.

in the $50^{\circ} \mathrm{C}$ group and 9.77 -fold in the $55^{\circ} \mathrm{C}$ group). TNF- $\alpha$ mRNA expression increased in the $50^{\circ} \mathrm{C}$ group (2.79-fold) and $55^{\circ} \mathrm{C}$ group (1.92-fold), and decreased in the $46^{\circ} \mathrm{C}$ group (0.65-fold), compared with that in the control group (Fig. 6).

Rechallenge in tumor-free mice. Tumor nodules appeared gradually in control mice implanted with melanoma cells, and evolved into rapid growth 6 days after implantation. Five tumor-free mice from the $50^{\circ} \mathrm{C}$ group and six from the $55^{\circ} \mathrm{C}$ group were implanted with melanoma cells. Mice in both hyperthermic groups survived and remained tumor-free for 60 days after implantation, indicating that they were protected completely from rechallenge with B16 cells. The tumor-free mice demonstrated an antitumor memory response to B16 cells (Figs. 7 and 8).

Pulmonary metastasis assay. On day 14, H\&E staining indicated areas of tumor in the lungs. Macroscopic observations were further confirmed by microscopic examination of lung samples, which revealed an obvious reduction of tumor cells in the lungs of group II mice administered hyperthermia alone. In group III mice (receiving C48/80 + hyperthermia), lungs were similar to normal lungs on visual inspection, with dotted or absent tumor cells noted on pathological observation. Traces 


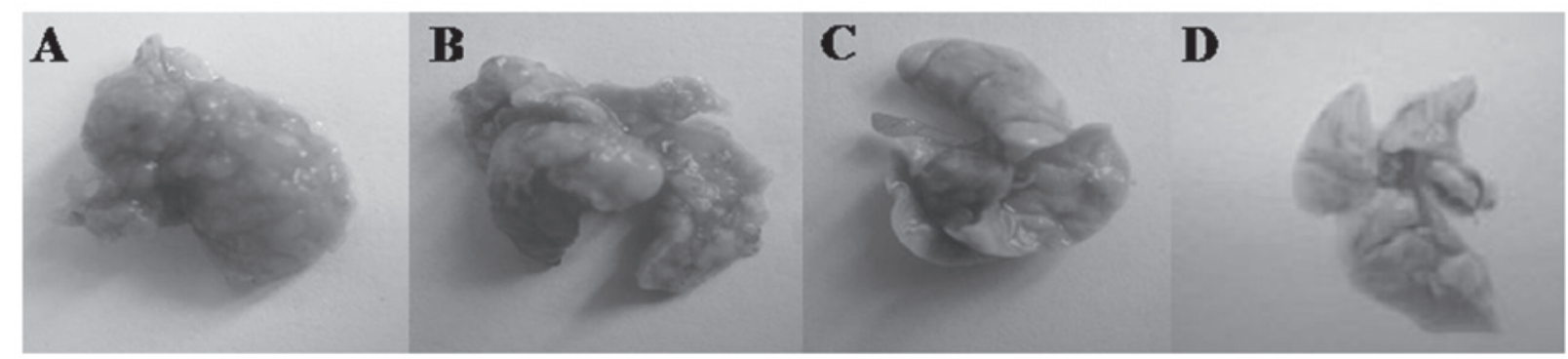

Figure 9. Lung tissue from murine model of melanoma pulmonary metastasis 14 days after hyperthermia treatment. (A) group I; (B) group II; (C) group III; (D) normal lung tissue. In group I, lung surfaces were densely covered with metastatic lesions. In group II, metastatic lesions appeared less frequently than in the control group. In group III, lung tissue was similar to normal lung tissue with no obvious metastatic tumor metastatic nodules observed.

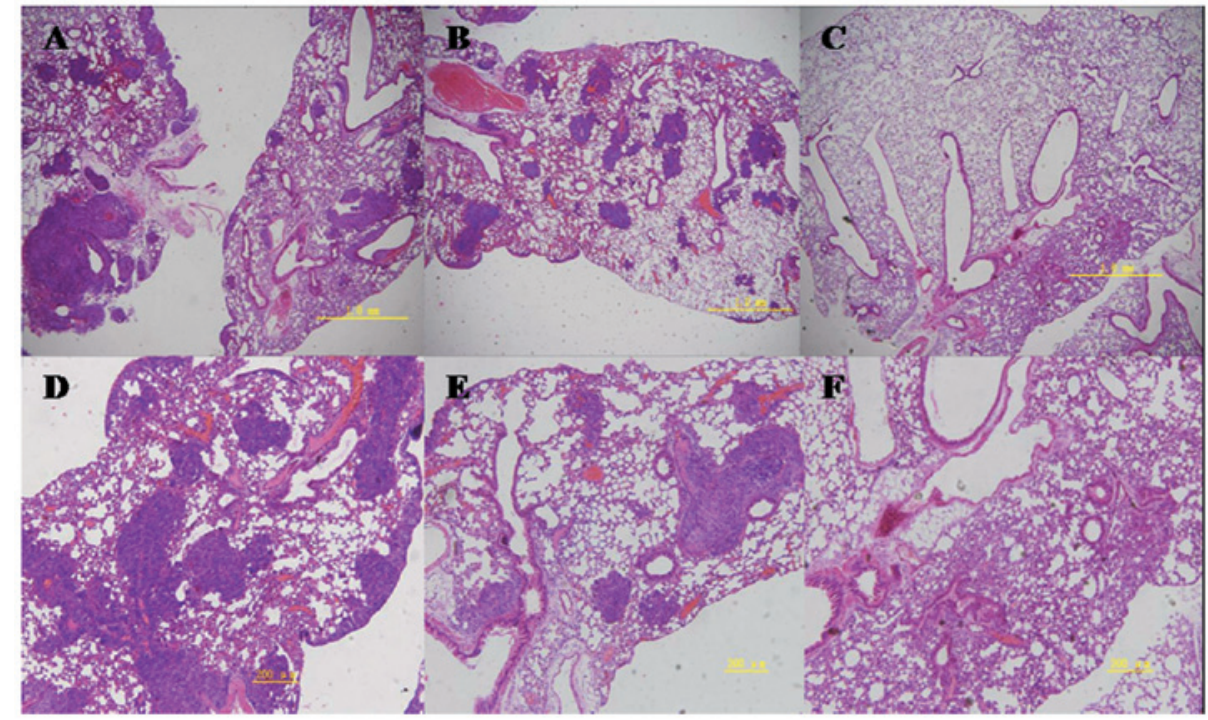

Figure 10. Histopathology of lung tissue in murine model of melanoma pulmonary metastasis with H\&E staining, 14 days after hyperthermia treatment. Magnification, (A, B, C) x200; bar, 1 mm. (D, E, F) x400; bar, $200 \mu \mathrm{m}$. (A and D) group I; (B and E) group II; (C and F) group III.

of inflammation were observed following tumor regression in the lungs of hyperthermically treated mice. In the control group, tumor cells were observed in a large area in the lungs of mice, with strong acidophilic staining, large nuclei, and with good reproductive potential (Figs. 9 and 10).

\section{Discussion}

In the present study, local high-temperature hyperthermia at 46 and $48^{\circ} \mathrm{C}$ for 15 min inhibited the growth, but did not induce regression, of subcutaneous B16 melanoma cells. Hyperthermia at $50^{\circ} \mathrm{C}$ for $15 \mathrm{~min}$ and $55^{\circ} \mathrm{C}$ for $10 \mathrm{~min}$ induced complete tumor regression. However, in the $55^{\circ} \mathrm{C}$ group certain mice suffered skin burns and several suffered skin wound infection as a consequence. Mice treated with hyperthermia in the 50 and $55^{\circ} \mathrm{C}$ groups remained tumor-free and in healthy condition after being rechallenged with melanoma cells in situ. This suggests that local high-temperature hyperthermia at 50 and $55^{\circ} \mathrm{C}$ effectively stimulates an immune response in mice and creates an antitumor immune memory, as shown by the cytokine data. Overall, our data suggest that 50 and $55^{\circ} \mathrm{C}$ local hyperthermia is effective in the treatment of melanoma and may have potential clinical value.
The use of hyperthermia to treat cancer in the clinical practice is based on its direct cytotoxic effect and the resulting enhanced sensitivity to radiotherapy and chemotherapy, and heat-induced antitumor immune responses (16). In our study, pathological observations $16 \mathrm{~h}$ after hyperthermia treatment at $46-55^{\circ} \mathrm{C}$ revealed temperature-dependent tumor tissue changes, with varying degrees of necrosis, congestion and hemorrhage. Our specially designed biological hyperthermia platform was able to achieve a temperature between 50 and $55^{\circ} \mathrm{C}$, which was high enough to induce tumor cell necrosis. The necrotic tumor cells, destroyed by hyperthermia, released their intracellular contents including tumor antigenic peptides. Antigenic peptides are taken up by immature DCs and presented to T-cells via MHC class I and/or II antigens (17-19). We speculate that 50 and $55^{\circ} \mathrm{C}$ hyperthermia resulted in sufficient antigen exposure, due to tumor cell necrosis, to activate an immune response, which successfully defended the rechallenge with B16 melanoma cells and destroyed the ectopically transplanted tumors.

The antitumor immune effect is dominated by Thl CD4 $4^{+}$ $\mathrm{T}$ lymphocytes, which produce the cytokines IL-2, IFN- $\gamma$ and TNF- $\alpha$. Humoral immunity is associated with Th2 $\mathrm{CD} 4^{+}$ $\mathrm{T}$ lymphocytes, which produce the cytokines IL-4, IL-6 and 
IL-10 (20). The shift in Thl/Th2 balance towards Th2 has been shown to be associated with tumorigenesis and recurrence in numerous malignancies including melanoma (21). Shifting the Th1/Th2 balance towards Th1 responses results in tumor rejection, since Th1 pathways typically produce activation of cytotoxic T-cell lymphocytes (CTL), natural killer (NK) cells and macrophages and monocytes, all of which attack cancer cells and defend against tumor growth (22). Conversely, shifting the Th1/Th2 balance toward a Th2-mediated immunity prevents tumor rejection (23). The expression levels of IL-2, IFN $-\gamma$ and TNF- $\alpha$ are indices of the Thl immune response. Previously, it has been reported that hyperthermia induces a Th1-dominant immune response. The protein concentration of cytokines IL- 2, IFN- $\gamma$ and TNF- $\alpha$ was shown to increase in the peripheral blood following whole body or local hyperthermia (10,24-26). The spleen is the largest immune organ in the body, and contains a large number of lymphocytes. Cytokines secreted from cells in the spleen activate and enhance phagocytosis, migration and cytotoxic effects of polymorphonuclear leukocytes, monocytes and macrophages, contributing to a significant antitumor effect. In this study, IFN- $\gamma$, IL- 2 and TNF- $\alpha$ mRNA expression increased significantly in the spleens of mice 14 days after hyperthermia in the 50 and $55^{\circ} \mathrm{C}$ groups. The findings in the spleen experiments were identical to those in the antitumor effect experiments, in that hyperthermia treatment at $50^{\circ} \mathrm{C}$ for $15 \mathrm{~min}$ and $55^{\circ} \mathrm{C}$ for 10 min was superior to other temperatures used. The results may be explained by an analysis of the mechanisms involved in the antitumor effect. We hypothesize that enhanced Th1-type cytokine expression in the spleen is associated with the enhancement of the antitumor effects found in this study. As mentioned previously, the high expression of cytokines in the spleen activates CTLs, NK cells, macrophages and monocytes, and results in increased death of tumor cells in situ. However, the expression of TNF- $\alpha$ mRNA in the spleen decreased slightly in the $46^{\circ} \mathrm{C}$ group compared with those in the control group, while TNF- $\alpha$ protein was found to be either increased or unchanged in serum following early ablation (10) or mild hyperthermia (26). Further investigation is needed to explain these divergent results. At day 7 following hyperthermia treatment, there was no significant increase in IL-2, IFN- $\gamma$ and TNF- $\alpha$ mRNA levels in any of the treatment groups compared with those in the control group. This is similar to and can be explained by the study of Zhou et al, who reported that one to two weeks were needed following ablation treatment $\left(85-95^{\circ} \mathrm{C}\right.$ for $3 \mathrm{~min}$ ) for necrotic tumor tissues to be absorbed, so that the immunosuppression induced by the burning of mice skin during heating decreased and the antitumor immune response would occur (11).

Overall, hyperthermia at $50^{\circ} \mathrm{C}$ for $15 \mathrm{~min}$ and $55^{\circ} \mathrm{C}$ for $10 \mathrm{~min}$ were the most effective treatment regimens used to control tumor growth and stimulate an immune response. Although $55^{\circ} \mathrm{C}$ for 10 min was the most effective treatment regime, it involved a high risk of skin burn injury and dehydration in mice. Thus, $50^{\circ} \mathrm{C}$ for $15 \mathrm{~min}$ was considered the optimal treatment regime for melanoma. Hyperthermia at $50^{\circ} \mathrm{C}$ for $15 \mathrm{~min}$ for the treatment of lung metastases was not fully effective. However, the lungs of mice treated with $50^{\circ} \mathrm{C}$ hyperthermia and C48/80 showed no tumor nodes on macroscopic analysis, and no obvious tumor cells on microscopic analysis. Local hyperthermia at the optimal thermal dose in combination with immunoadjuvant $\mathrm{C} 48 / 80$ is an effective approach for treating B16 melanoma lung metastasis. Local hyperthermia increased the infiltration of leukocytes, including mast cells at the site of tumors (27). The adjuvant activity of C48/80 was associated with its ability to induce DC migration via a mechanism that required mast cells and mast cell-derived TNF (14). Furthermore, McGowen et al reported that $\mathrm{C} 48 / 80$ produced much greater levels of IFN than it did IL-4, IL-5, IL-6 or IL-17, and reduced the IgG1/IgG2a ratio. Therefore they considered it possible that $\mathrm{C} 48 / 80$ acts through the connective tissue mast cells to stimulate an environment favorable for the development of Th1 immune responses (15). Based on the above, synergy may be created by the combined treatment of $\mathrm{C} 48 / 80$ and local hyperthermia, which form an effective resistance to lung metastasis in the therapy for lung metastasis treatment. Research on the mechanisms of this combined treatment requires further development.

In conclusion, we have shown that local high-temperature hyperthermia at $50^{\circ} \mathrm{C}$ for $15 \mathrm{~min}$ and $55^{\circ} \mathrm{C}$ for $10 \mathrm{~min}$ is effective in treating melanoma in mice, with $55^{\circ} \mathrm{C}$ for 10 min being particularly effective. Additionally, local hyperthermia at $50^{\circ} \mathrm{C}$ for $15 \mathrm{~min}$ in combination with the immune adjuvant compound 48/80 was effective in the treatment of B16 murine lung melanoma metastases. The significant inhibition of tumor growth by hyperthermia is likely due to a synergistic effect of direct cytotoxicity by heating, and induction of an antitumor immune response elicited by antigen release from necrotic tumor cells. The increased secretion of Th1-type cytokines in the spleen following hyperthermic treatment is also likely to participate in the antitumor immune response. Additional research on the application of high-temperature hyperthermia and C48/80 for in situ melanoma and treatment of lung metastases is warranted in order to translate the treatment to a clinical setting.

\section{Acknowledgements}

This study was supported by the National Natural Science Foundation of China under grant 30571779. The authors alone are responsible for the content and writing of this paper.

\section{References}

1. Thompson JF, Scolyer RA and Kefford RF: Cutaneous melanoma. Lancet 365: 687-701, 2005.

2. Sondak VK, Gonzalez RJ and Kudchadkar R: Adjuvant therapy for melanoma: a surgical perspective. Surg Oncol Clin N Am 20: 105-114, 2011.

3. Hong M, Puaux AL, Huang C, Loumagne L, Tow C, Abastado J, et al: Chemotherapy induces intratumoral expression of chemokines in cutaneous melanoma, favoring T-cell infiltration and tumor control. Cancer Res 71: 6997-7009, 2011.

4. McLoughlin JM, Zager JS, Sondak VK and Berk LB: Treatment options for limited or symptomatic metastatic melanoma. Cancer Control 15: 239-247, 2008.

5. Chicheł A, Skowronek J, Kubaszewska M and Kanikowski M: Hyperthermia - description of a method and a review of clinical applications. Rep Pract Oncol Radiother 12: 267-275, 2007.

6. Soares PI, Ferreira IM, Igreja RA, Novo CM and Borges JP: Application of hyperthermia for cancer treatment: recent patents review. Recent Pat Anticancer Drug Discov 7: 64-73, 2012.

7. Pace M, Gattai R, Mascitelli EM and Millanta L: Results of isolated lower limb perfusion for loco-regional advanced/ recurrent melanoma using borderline true hyperthermia plus additional bolus of melphalan. A critical analysis of homogeneous cases. J Surg Oncol 104: 718-723, 2011. 
8. Stojkovic R and Radacic M: Cell killing of melanoma B16 in vivo by hyperthermia and cytotoxins. Int J Hyperther 18: 62-71, 2002.

9. Ito A, Fujioka M, Yoshida T, et al: 4-S-Cysteaminylphenolloaded magnetite cationic liposomes for combination therapy of hyperthermia with chemotherapy against malignant melanoma. Cancer Sci 98: 424-430, 2007.

10. Haen SP, Pereira PL, Salih HR, Rammensee HG and Gouttefangeas C: More than just tumor destruction: immunomodulation by thermal ablation of cancer. Clin Dev Immunol 10 55-74, 2011.

11. Zhou ZX, Yin XY, Lv MD, et al: Homing of dendritic cells injected into the mouse hepatoma after microwave ablation under different temperature. Chinese J Pathophys 22: 355-359, 2006.

12. Paton WDM: Compound 48/80: a potent histamine liberator. Brit J Pharmacol 6: 499-508, 1951.

13. Rothschild AM: Mechanisms of histamine release by compound 48/80. Brit J Pharmacol 38: 253-262, 1970

14. McLachlan JB, Shelburne CP, Hart JP, et al: Mast cell activators: a new class of highly effective vaccine adjuvants. Nat Med 14: 536-541, 2008.

15. McGowen AL, Hale LP, Shelburne CP, Abraham SN and Staats HF: The mast cell activator compound $48 / 80$ is safe and effective when used as an adjuvant for intradermal immunization with Bacillus anthracis protective antigen. Vaccine 27: 3544-3552, 2009.

16. Dayanc BE, Beachy SH, Ostberg JR and Repasky EA: Dissecting the role of hyperthermia in natural killer cell mediated antitumor responses. Int J Hyperther 24: 41-56, 2008.

17. Dewey WC: Arrhenius relationships from the molecule and cell to the clinic. Int J Hyperthermia 10: 57-83, 1994.

18. Kayihan E: Biological rationale and clinical experience with hyperthermia. Clin Trials 17: 316-342, 1996.
19. Tanaka K, Ito A, Kobayashi T, et al: Heat immunotherapy using magnetic nanoparticles and dendritic cells for T-lymphoma. J Biosci Bioeng 100: 112-115, 2005.

20. Kidd P: Th1/Th2 balance: the hypothesis, its limitations, and implications for health and disease. Altern Med Rev 8: 23-46, 2003.

21. Laueroval L, Dusek L, Simickova M, et al: Malignant melanoma associates with Th1/Th2 imbalance that coincides with disease progression and immunotherapy response. Neoplasma 49: 159-166, 2002.

22. Terabe M, Park JM and Berzofsky JA: Role of IL-13 in regulation of anti-tumor immunity and tumor growth. Cancer Immunol Immunother 53: 79-85, 2004.

23. Romagnani S: The Th1/Th2 paradigm. Immunol Today 18: 3-6, 1997.

24. Sheeja K and Kuttan G: Effect of Andrographis paniculata as an adjuvant in combined chemo-radio and whole body hyperthermia treatment - a preliminary study. Immunopharmacol Immunotoxicol 30: 181-194, 2008

25. Den Brok MH, Sutmuller RPM, Van der Voort R, et al: In situ tumor ablation creats an antigen source for the generation of antitumor immunity. Cancer Res 64: 4024-4029, 2004.

26. Jia D, Liu J, Rao W, et al: Inhibition of B16 murine melanoma metastasis and enhancement of immunity by fever-range whole body hyperthermia. Int J Hyperther 27: 275-285, 2011.

27. Morita M, Kuwano H, Araki K, Egashira A, Kawaguchi H, Saeki H, et al: Prognostic significance of lymphocyte infiltration following preoperative chemoradiotherapy and hyperthermia for esophageal cancer. Int J Radiat Oncol Biol Phys 49: 1259-1266, 2001. 